\title{
HUBUNGAN LINGKUNGAN KAMPUS, POLA ASUH ORANG TUA DAN MOTIVASI BERPRESTASI MAHASISWA FAKULTAS EKONOMI UNIVERSITAS NEGERI JAKARTA
}

\author{
Oleh \\ Agus Wibowo \\ agus-wibowo@unj.ac.id
}

\begin{abstract}
Penelitian ini bertujuan untuk mengetahui: (1) hubungan antara lingkungan kampus dengan motivasi berprestasi mahasiswa FE-UNJ; (2) hubungan antara perhatian orang tua dengan motivasi berprestasi mahasiswa FE-UNJ, dan (3) hubungan antara lingkungan kampus dan pola asuh orang tua dengan motivasi berprestasi mahasiswa FE-UNJ.

Penelitian ini menggunakan metode survei dengan pendekatan korelasi. Hasil penelitian menunjukan bahwa: (1) ada korelasi signifikan antara lingkungan kampus dengan motivasi berprestasi mahasiswa FE-UNJ, di mana koefisien korelasi ganda $\left(\mathrm{R}_{\mathrm{y} .12}\right)=0,196$ dan $\mathrm{F}$ hitung $(\mathrm{F}$ Change $)=11,144$, serta $\mathrm{p}$-value $=0,040<0,05$. (2) ada hubungan yang signifikan antara pola asuh orang tua terhadap motivasi berprestasi mahasiswa FE-UNJ, di mana koefisien korelasi $\mathrm{X}_{2} \mathrm{ke} \mathrm{Y}$ sebesar 0,102 dengan nilai signifikansi 0,000 $\leq 0,050$. Hasil hitung koefisien korelasi ganda $\left(\mathrm{R}_{\mathrm{y} .12}\right)=0,410$ dan $\mathrm{F}$ hitung $(\mathrm{F}$ Change $)=21,817$, serta $\mathrm{p}$-value $=$ $0,000<0,05$. Sedangkan koefisien determinasinya, yaitu $\mathrm{R}$ square $=0,168$, (3) ada hubungan yang signifikan antara lingkungan kampus dan pola asuh orang tua terhadap motivasi berprestasi mahasiswa FE-UNJ di mana hasil perhitungan uji koefisien korelasi ganda $\left(\mathrm{R}_{\mathrm{y} .12}\right)$ $=0,415$ dan $\mathrm{F}$ hitung $(\mathrm{F}$ Change $)=11,144$, serta $\mathrm{p}$-value $=0,000<0,05$. Sedangkan koefisien determinasinya, yaitu $\mathrm{R}$ square $=0,172$.
\end{abstract}

Kata Kunci:Lingkungan Kampus, Pola Asuh Orang Tua, Motivasi Berprestasi.

This study aims to determine: (1) the relationship between campus environment with student achievement motivation FE-UNJ; (2) the relationship between the parents' attention with student achievement motivation FE-UNJ, and (3) the relationship between campus environment and parenting patterns with student achievement motivation FE-UNJ.

This study used survey method with correlation approach. The results showed that: (1) there is a significant correlation between campus environment with student achievement motivation FE-UNJ, which isthe multiple correlation coefficient $\left(R_{y \cdot 12}\right)=0.196$ and $F$ count $(F$ Change $)=11.144$, and the $p$-value $=0,040<0.05$. (2) there is a significant relationship between parenting patterns on student achievement motivation FE-UNJ, which is the correlation coefficient $X_{2}$ to $Y$ at 0.102 with a significance value of $0,000 \leq 0,050$. The results of multiple correlation coefficient $\left(R_{y \cdot 12}\right)=0.410$ and $F$ count $(F$ Change $)=21.817$, and the $p$-value $=0.000<0.05$. While the coefficient of determination, the $R$ square $=0.168$, (3) there is a significant relationship between campus environment and the parenting pattern of student achievement motivation FE-UNJ in which the results of test calculations multiple correlation coefficient $\left(R_{y \cdot 12}\right)=0.415$ and $F$ count $(F$ Change $)=11.144$, and the p-value $=$ $0.000<0.05$. While the coefficient of determination, the $R$ square $=0.172$.

Keywords: Environmental Campus, Parenting Pattern, Achievement Motivation. 


\section{LATAR BELAKANG}

Laju perkembangan ilmu pengetahuan dan teknologi (IPTEK) yang amat pesat, menuntut ketersediaan sumberdaya manusia (SDM) yang berkualitas tinggi. SDM demikian merupakan output atau lulusan dari proses pendidikan yang bermutu. Adapun pendidikan adalah usaha sadar untuk mengembangkan potensi diri peserta didik, melalui kegiatan belajar mengajar (Depdagri, 2003: 22).

Kualitas SDM ini dapat 1 iukur melalui prestasi yang dicapai dalam proses pembelajaran. Salah satu jalur pendidikan formal adalah Perguruan Tinggi. Perguruan Tinggi diharapkan mampu menghasilkan SDM yang berkualitas, yaitu SDM yang berprestasi. Namun kenyataannya, dalam kegiatan pembelajaran masih ada mahasiswa yang mengalami masa studi melebihi batas aturan jenjang strata satu atau S1 (lebih dari batas waktu tujuh tahun). Hal ini disebabkan oleh beberapa faktor yang mempengaruhinya. Lingkungan kampus terutama, memiliki peran penting bagi mahasiswa dan prestasi yang mereka capai.

Kampus memiliki peranan penting bagi kegiatan belajar mahasiswa. Sebab, jika kampus mampu memberikan fasilitas sarana dan prasarana yang baik maka mahasiswa akan merasa nyaman ketika mengikuti kegiatan perkuliahan. Selain itu, kampus yang berwawasan lingkungan khususnya di wilayah perkotaan, bukan hanya sangat dianjurkan, tetapi juga dituntut keberadaannya. Apalagi, saat ini di daerah perkotaan ruang terbuka hijau semakin sempit, masih ditambah dengan tingkat polusi udara yang tinggi.

Di sisi lain, upaya menciptakan suasana kampus yang ramah lingkungan dengan menanam berbagai tumbuhan di lingkungannya, juga bukan hal yang mudah untuk dilakukan. Fenomena demikian seperti disampaikan oleh Supriyanto, kepada kabarkota.com, usai menerima penghargaan sekolah dan kampus atau sekolah berwawasan lingkungan kota Yogyakarta. Salah satu tantangan terberat, kata Supriyanto, justru berasal dari dosen di kampus atau para guru di sekolah tersebut." Tantangannya terkait kebersamaan dan kepedulian dari paraguru atau para dosen yang masih minim," kata Supriyanto.

Masalah lingkungan di kampus yang masih kurang mendukung dan kurang kondusif terhadap proses belajar mengajar tersebut, tentu saja dapat mengganggu motivasi dan konsentrasi belajar di kelas. Oleh karena itu, pihak kampus semestinya menjamin ketenangan dan rasa nyaman dengan menciptakan lingkungan yang bersih. 
Selain masalah lingkungan sebagaimana telah dijelaskan, kurangnya perhatian orang tua terhadap anak juga dapat menimbulkan efek buruk baik perilakunya di lingkungan masyarakat, maupun di lingkungan kampus. Anak-anak dengan pola asuh yang buruk dan kurang mendapatkan perhatian dari orang tuanya, akan memakai cara sendiri guna mendapatkan perhatian dari orang lain. Jika cara yang dilakukan oleh anak benar itu tidak menjadi masalah, tetapi sebagian besar mereka akan mempergunakan cara yang salah. Maka sebaiknya orang tua harus memberikan perhatian yang cukup terhadap anak-anaknya. Pola asuh dan perhatian ini tentu tidak hanya aspek fisik saja, tetapi juga perhatian yang mendukung perkembangan emosi anak. Perhatian orang tua yang cukup ini, memungkinkan anak memiliki kualitas kepribadian yang baik.

Akibat kurang perhatian orang tua terhadap anaknya, akan terjadi hal-hal yang tidak diinginkan. Misalnya karena kesibukan para orang tua dalam pekerjaan menjadi penghalang untuk berkomunikasi dengan anak mereka. Apalagi, anak yang sudah memasuki usai remaja karena jiwanya labil, para remaja itu lebih suka menyampaikan permasalahan yang dihadapinya kepada teman sebaya ketimbang orang tuanya. Mestinya, orang tua tidak boleh membiarkan anak hidup tanpa kasih sayang, karena bisa menimbulkan masalah bagi tumbuh kembang mereka.

Apalagi, pasca remaja merupakan usia yang mencangkup kematangan mental, emosional, sosial dan fisik. Pada masa ini, beberapa faktor tersebut bisa saling berbenturan. Para orang tua pun dibuat kerepotan menghadapi masa-masa pasca pubertas remaja tersebut. Padahal, rumah merupakan basis dari bimbingan orang tua dalam membangun kepribadian pasca remaja.

Pengawasan, idealnya bukan dilakukan dengan cara mengekang dan melarang anak tanpa alasan. Itu artinya, orang tua tidak perlu melarang anak selama apa yang mereka lakukan masih wajar. Dengan kata lain, tidak membahayakan dan merugikan diri anak sendiri, norma masyarakat, hukum, agama, dan orang lain di sekitarnya. Hal senada disampaikan Anis Diah Ayu Masita (2015), salah seorang perintis Rumah Hebat Indonesia (RHI). Di kawasan padat penduduk, tulis Anis, permasalahan sosial sangat beragam sehingga anak berperilaku buruk.

Kondisi sebagaimana diuraikan pada paragraf sebelumnya, kurang diperhatikan para orang tua. Seringnya, orang tua menyalahkan dosen dan kampus karena 
dinilai rendah dalam memotivasi anak mereka untuk belajar. Padahal, menurut Sylvia Rimm dalam bukunya Smart Parenting: How to Raise a Happy Achieving Child, orang tua memiliki pengaruh positif yang sangat besar terhadap pendidikan anak-anaknya. Tidak hanya ketika anak masih kecil, namun juga sepanjang hidupnya. Anak cenderung meniru sifat dan perilaku kedua orang tua mereka, baik melalui penglihatan, pendengaran, juga yang dirasakan sang anak atas perlakuan orang tua terhadap mereka. Inilah mengapa pola asuh orang tua terhadap anak menjadi penting, tak luput halnya dalam pendidikan yang di dalamnya dapat berpengaruh terhadap motivasi anak untuk berprestasi.

Pola asuh orang tua terhadap anaknya harus dijaga dengan baik. Orang tua, selain memberikan pola asuh yang baik, juga dituntut untuk tidak memberikan kesempatan anak lebih senang berbicara dengan temannya. Singkatnya, orang tua harus menjadi tempat menyampaikan segala persoalan anak dengan porsi lebih. Sebagaimana telah diuraikan sebelumnya, orang tua mempunyai pengaruh yang sangat besar terhadap keberhasilan anak dalam belajar. Untuk meningkatkan motivasi berprestasi anak, orang tua harus mendidiknya dengan baik. Maka, dibutuhkan kesadaran para orang tua akan pentingnya pendidikan anak di dalam keluarga. Kesadaran para orang tua ini, akan mendorong mereka untuk mendidik anak-anaknya sejak kecil, demi mengembangkan segala potensi yang masih terpendam.

Studi mengenai motivasi berprestasi cukup banyak dijumpai di berbagai literatur psikologi dan pembelajaran. Namun, studi ini untuk pertama kali diperkenalkan lewat taksonomi Murray. Dalam taksonomi Murray tersebut, dijelaskan mengenai sistem kebutuhan dan dilanjutkan dengan pengembangan TAT (Thematic Apperception Test) guna mengetahui gambaran motivasi seseorang. Muray dalam taksonominya itu, sampai pada kesimpulan bahwa n-ach sebagai kebutuhan untuk menyelesaikan sesuatu yang sulit, menguasai sesuatu dengan cepat dan mandiri, menyelesaikan permasalahan dan mencapai standar yang tinggi, menantang diri sendiri, bersaing dan mengungguli orang lain, mengembangkan penguasaan atas objek fisik, kemanusiaan dan ide, serta melakukan semua hal tersebut sebagai sebuah kebanggaan dengan latihan-latihan yang baik (Hall, C \& Lindsey, 1995)

Selanjutnya, McClelland (dalam Muhammad, 2008: 9) mendefinisikan motivasi berprestasi sebagai "impetus to do well relative to some standard of 
excellence." Berdasarkan definisi McClelland tersebut dapat diketahui bahwa motivasi berprestasi merupakan dorongan untuk melakukan sesuai dengan standar keunggulan tertentu. Senada dengan McClelland, Schunk (2004: 36) mendefinisikan achievement motivation sebagai "the desire to excel at effortful activities," yaitu keinginan untuk unggul dalam suatu kegiatan usaha. Sementara Soegoto (2010: 52) mendefinisikan motivasi berprestasi secara spesifik, yaitu "motivasi yang akan memicu seseorang untuk terlibat dengan penuh rasa tanggung jawab, membutuhkan usaha dan keterampilan individu, terlibat dalam risiko sedang, dan memberikan masukan yang jelas."

Jika McClelland, Schunk, dan Soegoto mendefinisikan motivasi berprestasi secara ringkas dan spesifik, maka Heckhausen (via Falko Rheinberg, 2000: 89) mendefinisikannya secara lebih mendalam. Menurut Heckhausen, motivasi berprestasi adalah “a person's striving to improve his or her competence (or maintain it on the highest possible level) in all those activities where a person has committed himself or herself to a standard of excellence."

Berdasarkan definisi Heckhausen tersebut kita dapat mengetahui bahwa seseorang yang memiliki motivasi untuk berprestasi, akan selalu berusaha meningkatkan kompetensinya (atau bahkan mempertahankannya pada tingkat tertinggi), dalam setiap kegiatan yang dimiliki dengan berkomitmen terhadap dirinya sendiri pada suatu standar keunggulan.

Selanjutnya menurut Gallerman (via Makmun Khairani, 2014: 182), suatu cara berpikir tertentu apabila terjadi pada diri seseorang, akan membuat yang bersangkutan bertingkah laku secara lebih giat untuk meraih hasil atau prestasi tertentu. Prilaku sebagaimana diuraikan juga mencerminkan keberanian seseorang dalam menanggung segala risiko sebagai konsekuensi logis atas usaha yang dilakukannya.

Berdasarkan beberapa pengertian yang telah dijelaskan di atas, dapat disimpulkan bahwa motivasi berprestasi merupakan sebuah daya penggerak dalam diri yang memicu seseorang untuk terlibat dengan penuh rasa tanggung jawab, melakukan suatu usaha dan keterampilan individu, komitmen, terlibat dalam risiko sedang, dan memberikan input yang jelas demi meningkatkan kompetensi (atau mempertahankannya pada tingkat tertinggi) guna mencapai taraf prestasi setinggi mungkin, sesuai dengan suatu standar keunggulan sehingga dapat memperoleh hasil kerja yang optimal, serta 
menjadi bentuk kesenangan ketika berhasil memenangkan suatu persaingan.

Sebagaimana telah diuraikan pada paragraf sebelumnya, bisa kita ketahui bahwa setiap ahli memiliki pandangan yang tak jauh berbeda mengenai motivasi berprestasi. McClelland (via Mirza S. Saiyadain, 2006:47-49) membagi teori kebutuhan menjadi $n$-Ach (need for Achievement), n-Pow (need for Power), dan $n$-Aff (need for Affiliation). Menurut McClelland, seseorang yang memiliki motivasi berprestasi ( $n$-Ach) tinggi, memiliki ciri-ciri sebagai berikut: (1) take personal responsibility; (2) take moderate risks; (3) want to know the results of the efforts; (4) tends to persist in the face of adversity; (5) tends to be innovative; (6) usually demonstrates some interpersonal competence, dan (7) oriented towards the future.

Selanjutnya menurut Daniel Goleman (dalam Toto Tasmara, 2006:16) seseorang yang memiliki dorongan berprestasi itu memiliki ciri-ciri sebagai berikut: (1) beorientasi pada hasil, dengan semangat juang yang tinggi untuk meraih tujuan dan memenuhi standar; (2) menetapkan sasaran yang menantang dan berani mengambil risiko yang telah diperhitungkan; (3) mencari informasi sebanyak-banyaknya guna mengurangi ketidakpastian dan mencari cara yang lebih baik, dan (4) terus belajar untuk meningkatkan kinerja mereka.

Melengkapi Daniel Goleman, Khairani (2014: 184) menguraikan karakteristik seseorang yang mempunyai motivasi berprestasi tinggi, yaitu: (1) memiliki tanggung jawab pribadi yang tinggi; (2) memiliki program kegiatan berdasarkan rencana dan tujuan yang realistik serta berjuang untuk merealisasikannya;(3) memiliki kemampuan untuk mengambil keputusan dan berani mengambil risiko yang dihadapinya; (4) melakukan kegiatan yang berarti dan menyelesaikannya dengan hasil yang memuaskan; serta (5) mempunyai keinginan menjadi orang terkemuka yang menguasai bidang tertentu.

Selanjutnya Djaali (2009:109-110), meski sedikit berbeda dengan para ahli sebelumnya, menguraikan kharakteristik khas seseorang yang memiliki motivasi berprestasi tinggi. Menurut Djaali, seseorang yang memiliki motivasi berprestasi tinggi akan mempunyai ciri-ciri sebagai berikut: (1) menyukai situasi atau tugas yang menuntut tanggung jawab pribadi atas hasil-hasilnya dan bukan atas dasar untung-untungan, nasib, atau kebetulan; (2) memilih tujuan yang realistis tapi menantang dari tujuan yang terlalu mudah dicapai atau terlalu besar risikonya; (3) mencari situasi atau 
pekerjaan di mana ia memperoleh umpan balik dengan segera dan nyata untuk menentukan baik atau tidaknya hasil pekerjaannya; (4) senang bekerja sendiri dan bersaing untuk mengungguli orang lain; (5) mampu menangguhkan pemuasan keinginannya demi masa depan yang lebih baik; serta (6) tidak tergugah untuk sekadar mendapatkan uang, status, atau keuntungan lainnya, ia akan mencarinya apabila hal-hal tersebut merupakan lambang prestasi, suatu ukuran keberhasilan.

Berdasarkan pendapat dari para ahli sebagaimana telah diuraikan, maka dapat disimpulkan bahwa ciri-ciri orang yang memiliki motivasi berprestasi adalah mereka yang mengambil tanggung jawab pribadi, mengambil risiko moderat (sedang), ingin mengetahui hasil usaha, dan berorientasi pada masa depan.

\section{Lingkungan Kampus}

Sebagaimana telah diuraikan pada pembahasan sebelumnya, kampus merupakan lingkungan pendidikan formal. Dikatakan formal karena sebagaimana sekolah, di kampus juga terlaksana serangkaian kegiatan terencana dan terorganisasi, termasuk dalam rangka proses belajar-mengajar di kelas (Winkel, 1999: 28). Lingkungan kampus yang dimaksud terkait dengan metode mengajar dosen, kurikulum, relasi dosen dengan mahasiswa, relasi mahasiswa dengan mahasiswa, disiplin kampus, media pembelajaran, waktu perkuliahan, standar perkuliahan di atas ukuran, keadaan gedung, metode belajar dan tugas rumah.

Dimyati dan Mudjiono (2013: 249) mengemukakan bahwa prasarana pembelajaran meliputi gedung, ruang belajar, lapangan olahraga, ruang ibadah, ruang kesenian dan peralatan olahraga. Sedangkan sarana pemebalajaran meliputi buku pelajaran, buku bacaan, alat dan fasilitas laboratorium dan berbagai media pembelajaran yang lain.

Berdasarkan beberapa pendapat di atas dapat disimpulkan bahwa lingkungan kampus meliputi semua hal yang berpengaruh dan bermakna bagi mahasiswa saat menjalani proses perkuliahan di kampus, baik itu lingkungan sosial maupun lingkungan non-sosial (lingkungan fisik dan akademik).

Menurut Muhibbin Syah (2008: 135), lingkungan kampus, sebagaimana sekolah, terdiri dari dua macam; yaitu lingkungan sosial dan lingkungan fisik. Lingkungan sosial kampus seperti para dosen, para tenaga pendidikan, dan teman sekelas. Lingkungan fisik kampus meliputi gedung kampus, alat-alat belajar, cuaca, dan sebagainya. Lingkungan sosial kampus dapat mempengaruhi semangat belajar mahasiswa. Para dosen yang menunjukan 
sikap dan perilaku yang simpatik, memberikan dukungan dan motivasi kepada mahasiswa dan memperlihatkan teladan yang baik, serta rajin khususnya dalam hal belajar, misalnya rajin membaca dan berdiskusi, dapat menjadi daya dorong yang positif bagi kegiatan belajar mahasiswa."

Menurut Sukmadinata (2005: 164), lingkungan kampus_-dan juga lingkungan sekolah_-adalah lingkungan yang meliputi lingkungan fisik, lingkungan sosial, dan lingkungan akademis. Lingkungan fisik meliputi kelas, sarana dan prasarana belajar yang ada, sumber-sumber belajar, dan media belajar. Lingkungan sosial menyangkut hubungan mahasiswa dengan teman-temannya, dosen-dosennya, serta staf akademika kampus yang lain. Lingkungan akademis, yaitu sarana pelaksanaan kegiatan belajar-mengajar, berbagai kegiatan kokurikuler, dan lain sebagainya.

Dimyati dan Mudjiono (2013: 99), dengan sedikit diadaptasi penulis, mengemukakan bahwa lingkungan kampus yang indah dan pergulan mahasiswa yang rukun, akan memperkuat motivasi belajar. Oleh karena itu kondisi lingkungan kampus yang sehat, kerukunan hidup, dan ketertiban pergaulan perlu ditinggalkan untuk meningkatkan motivasi berprestasi mahasiswa.
Berdasarkan beberapa pendapat sebagaimana telah diuraikan dapat disimpulkan bahwa semakin baik lingkungan kampus, semakin baik pula prestasi belajar mahasiswa. Indikator lingkungan kampus dalam peneletian ini meliputi: keadaan kampus, tempat belajar, kualitas dan metode mengajar dosen, relasi mahasiswa dengan masyarakat kampus, keadaan fasilitas atau perlengkapan di kampus, dan pelaksanaan tata tertib kampus.

\section{Pola Asuh Orang Tua}

Pola asuh atau parenting style merupakan salah satu faktor yang secara signifikan turut membentuk kepribadian anak. Horlock mendefinisikan pola asuh orang tua sebagai metode yang digunakan orang tua dalam menjalin hubungan dengan anak-anaknya. Senada dengan McClelland（via Schultz \& Schultz, 1994) mendefinisikan pola asuh sebagai cara di mana orang tua bertindak terhadap anakanaknya, dengan melakukan serangkaian usaha secara aktif.

Maccoby (via Roberta M. Berns, 2010) mendefinisikan pola asuh orang tua sebagai:

"Parenting styles are usually classified by the dimensions of acceptancel responsiveness (warmth/sensitivity) and demandingness/control (permissiveness) restrictiveness). Parents who are accepting 
Iresponsive give affection, provide encouragement, and are sensitive to their children's needs; parents who are unaccepting/unresponsive are rejecting, critical, and insensitive to their children's needs. Parents who are demanding/ controlling set rules for children and monitor their compliance; parents who are undemanding/ uncontrolling make few demands on children and allow them much autonomy. Parents who are neither responsive nor demanding are considered to be indifferent, or uninvolved."

Syamsu Yusuf (2000: 48) mendefinisikan pola asuh orang tua sebagai pola sikap dalam mendidik dan memberikan pelakuan terhadap anak. Senada dengan Syamsu Yusuf, Gunarso (2000: 44) mendefinisikan pola asuh orang tua sebagai metode atau cara yang dipilih orang tua dalam mendidik anak-anaknya. Sementara menurut menurut Kohn (dalam Chabib Thoha, 1996: 109) pola asuh merupakan sikap orang tua dalam berhubungan dengan anaknya. Sikap ini dapat dilihat dari berbagai segi, antara lain dari cara orang tua memberikan pengaturan kepada anak, cara memberikan hadiah dan hukuman, cara orang tua menunjukkan otoritas dan cara orang tua memberikan perhatian, tanggapan terhadap keinginan anak. Berdasarkan beberapa pendapat sebagaimana telah diuraikan, dapat disimpulkan bahwa pola asuh orang tua adalah pola sikap, metode dan cara bertindak, orang tua terhadap anakanaknya. Tujuan pola asuh orang tua adalah mendidik anak agarsesuai dengan potensi dan perkembangannya.

Menurut McClelland, model pola asuh orang tua sangat berpengaruh terhadap motivasi berprestasi anak. Pada keluarga yang sehat dan bahagia, kata McClelland, pola asuh orang tua memotivasi anak untuk berprestasi. Orang tua model ini memberikan dorongan kepada anak untuk tidak menyerah, dan berusaha menyelesaikan tugas-tugasnya meski sulit sekalipun. Orang tua ini akan melarang anaknya mengeluh ketika menemui kesulitan atau kegagalan. Sebaliknya, orang tua model ini akan mendorong anak-anak mereka menemukan strategi dan cara terbaik menyelesaikan kesulitan atau menggapai kesuksesan. Ketika anak telah berhasil mengatasi kesulitan atau menggapai kesuksesan, orang tua tak akan segan memberikan apresiasi, pujian bahkan hadiah.

Senada dengan McClelland, Rohner (via Dyah Retno Palupi, 2013: 3) sampai pada kesimpulan bahwa pola asuh berpengaruh pada belajar dan prestasi belajar anak. Pola asuh juga menjadi prediktor yang memengaruhi perkembangan dalam kemampuan sosial, akademik, perkembangan psikososial, bahkan pembentukan prilaku yang 
bermasalah.Begitu penting dan berartinya pola asuh orang tua terhadap anak, sampaisampai Rohner menyimpulkan bahwa pengalaman masa kecil seseorang sangat mempengaruhi perkembangan kepribadian- nya kelak termasuk karakter atau kecerdasan emosinya. Penelitian Rohner yang menggunakan teori PAR (Parental Acceptance-Rejection Theory) ini juga menyimpulkan bahwa pola asuh orang tua, baik yang menerima (acceptance) atau yang menolak (rejection) anaknya, akan mempengaruhi perkembangan emosi, perilaku, sosialkognitif, dan kesehatan fungsi psikologisnya ketika dewasa kelak.

Senada dengan McClelland dan Rohner, Haditono (via Mönks \& Knoers,1999) menegaskan bahwa pola asuh orang tua dapat mempengaruhi pembentukan motivasi berprestasi pada anak, serta mendorongnya melebihi standar keunggulan.

Umumnya, anak mengharapkan pujian dari orang tua. Apabila orang tua tidak memberikan pujian kepada anak, maka ia akan menjadi pemalas dan tidak mau belajar. Dengan demikian, jangankan prestasi belajarnya tinggi, bisa jadi anak akan mengalami kemunduran dalam hal prestasi belajarnya.

Menurut Berger (via Gary D. Borich, 1995: 647), pola asuh dan perhatian orang tua terhadap anak sangat penting sekali, bahkan menjadi salah satu penentu keberhasilan anak dalam belajar. Sebagaimana diungkap Berger,

\section{"Parenting style}

andparentssparticipationactivities that involved educating parents to their children have been the most succesful for improving learner achivment (Pola asuh dan kegiatan partisipasi orang tua yang melibatkan pendidikan dari orang tua kepada anak-anaknya telah menjadi suatu keberhasilan dalam meningkatkan prestasi siswa)."

Sementara menurut Crider (via Saifuddin Azwar, 1996:4), pola asuh dan perhatian yang diberikan orang tua kepada anaknya dalam hal ini pendidikan, sangatlah penting untuk hasil optimal dalam pembelajaran anak di sekolah. Keterlibatan orang tua dalam hal ini harus diutamakan, ini dikarenakan anak sangat membutuhkan pendamping dan bimbingan dalam proses belajarnya. Misalnya, seorang anak yang memiliki kesulitan dalam pembelajaran di sekolah memerlukan bimbingan dari orang tua di rumah untuk membantunya memberikan pertolongan terhadap kesulitannya. Kemudian apabila orang tua dapat mengajarkan cara pembelajaran yang baik bagi anak maka akan membantu anak 
tersebut dalam pembelajarannya di sekolah.

Pola asuh dan perhatian orang tua terhadap anak tidak lepas dari keterlibatan orang tua dan tanggung jawab orang tua dalam mendukung pembentukan seorang anak. Menurut Covey (via Syamsu Yusuf, 2000: 48) orang tua dalam hal ini memiliki keterlibatan sebagai: (1) Modelling, orang tua adalah contoh atau model bagi anak. Tidak dapat disangkal bahwa orang tua mempunyai pengaruh yang sangat kuat bagi anak. Melalui modelling ini anak akan belajar mengenai sikap proaktif, dan sikap respek serta kasih sayang; (2) Mentoring, orang tua merupakan mentor pertama bagi anak yang menjalin hubungan dan memberikan kasih sayang secara mendalam, baik secra positif atau negatif, orang tua mau tidak mau menjadi mentor bagi anak, dan (3) Teaching, orang tua berperan sebagai guru(pengajar) bagi anakanak tentang hukum-hukum dasar kehidupan. Peran orang tua sebagai guru adalah mengajarkan tentang apa yang mereka kerjakan dan alasan tentang mengapa mereka mengerjakan itu.

Menurut Hurlock (1990: 205), orang tua dalan pola pengasuhan memberlakukan berbagai macam metode dengan tujuan mendidik anaknya. Pemilihan metode ini memiliki peranan penting, sebab terbentuknya pendidikan anak tergantung pada metode pendidikan yang digunakan. Adapun beberapa metode yang dipilih orang tua di antaranya otoriter, permisif, atau demokratis, sebagian akan bergantung pada cara mereka sendiri dibesarkan, dan sebagian pada apa yang berdasarkan pengalaman pribadi atau pengalaman teman, diketahuinya akan menghasilkan hasil yang diinginkannya untuk anaknya kelak.

Menurut Dawn Lighter (1999: 18), tipe Autoritarian dengan karakteristik: orang tua sangat keras dan kuat, mengancam dalam beberapa hal, anak dipaksa untuk menerima nilai-nilai yang mereka ajarkan dan mematuhi cara mereka melakukan segala sesuatu pada setiap saat. Tipe Permisif karakternya anak tumbuh dalam sebuah rumah yang penuh dengan rasa cinta, namun sama sekali tidak ada aturan dan disiplin. Hanya terdapat sedikit permintaan dan batasan atau larangan yang dikenakan pada anak. Anak tidak pernah dihukum atau diberi hadiah. Selanjutnya tipe Autoritatif, di mana orang tua mengajarkan kepada anak dengan berbagai cara, mereka mengajarkan menganai berlaku secara dewasa dan dengan cara bertanggung jawab, serta memberikan hadiah jika anak melakukukan hal yang diminta oleh orang tuanya. Orang tua juga sangat mencintai dan mengungkapkan afeksi kepada anak. Anak akan merasa 
benar-benar didengarkan oleh orang tua dan orang tua mendorong anaknya untuk berpikir sendiri. Aturan-aturan yang diberlakukan di rumah cukup beralasan. Ada beberapa konsekuensi bila anak melanggar peraturan. Anak akan tumbuh dengan kecakapan untuk menjadi mandiri.

Terkait dengan prilaku sosial anak, Diana Baumrind (via Syamsu Yusuf, 2000: 54) menyebut tipe orang tua otoritarian sebagai mereka yang mengutamakan kontrol dan kepatuhan tanpa syarat kepada anak mereka. Orang tua ini beranggapan bahwa semua yang telah ditetapkan harus mutlak dipatuhi oleh anak-anaknya tanpa ada pengecualian sedikitpun dan apabila anaknya melakukan pelanggaran terhadap ketetapan tersebut, mereka harus dihukum secara keras agar tidak menngulangi perbuatannya lagi. Pada umumnya, anakanak yang dididik secara otoritarian ini tumbuh menjadi anak yang susah bergaul dengan orang banyak dan sulit percaya kepada orang lain.

Orang tua permisif, lanjut Diana Baumrind, sangat menghargai ekspresi diri dan regulasi diri. Ketika ingin membuat suatu peraturan, mereka akan menjelaskan kepada anak-anaknya terlebih dahulu mengapa peraturan tersebut dibuat. Mereka juga akan berdiskusi dengan anak-anaknya tentang suatu keputusan atau kebijakan apa yang harus diambil. Orang tua permisif ini sangat jarang memberi hukuman pada anaknya sehingga biasanya akan menyebabkan anak-anak mereka tumbuh menjadi pribadi yang tidak dewasa dan kurang kontrol diri.

Sementara orangtua autoritatif, simpul Diana Baumrind, sangat menghargai individualitas anak tetapi juga menekankan batasan sosial. Mereka mencintai dan menerima tetapi menuntut perilaku yang baik. Orangtua yang autoritatif ini kokoh dalam mempertahankan standar dan menjatuhkan hukuman yang bijaksana kepada anak ketika mereka melakukan kesalahan, akan tetapi tetap dalam konteks yang hangat dan suportif, mereka juga memberi pengertian kepada anak tentang suatu tindakan yang dilakukannya sehingga anak-anak mereka merasa sangat aman karena mereka mengetahui bahwa dirinya begitu dicintai oleh orangtuanya. Anak-anak yang orangtuanya autoritatif akan tumbuh menjadi pribadi yang mandiri dan tegas.

Berdasarkan uraian-uraian di atas dapat diketahui bahwa untuk pola asuh orang tua dalam mendidik anak yang efektif adalah dengan menggunakan metode autoritatif. Itu karena metode tersebut lebih berorientasi terhadap keberhasilan pembelajaran anak dibandingkan dengan metode lainnya. Selain itu metode efektif dalam mendidik 
anak adalah metode autoritatif. Sebab, metode tersebut dapat membentuk anak menjadi lebih baik dan bisa berorientasi pada keberhasilan pembelajaran.

Metode autoritatif yang berorientasi kepada keberhasilan pembelajaran anak, salah satunya berisi tentang sikap acceptance atau penerimaan orang tua terhadap anaknya. Adanya penerimaan orang tua kepada anaknya mengindikasikan banyaknya perhatian yang diberikan orang tua kepada anaknya. Menurut Schneiders dan Lore sikap penerimaan mengidentifikasikan adanya perilaku orang tua yang terdiri dari: memberikan perhatian dan cinta kasih yang tulus kepada anak, menempatkan anak dalam posisi yang penting di rumah, mengembangkan hubungan yang hangat dengan anak, bersikap respek terhadap anak, mendorong anak untuk menyatakan perasaan atau pendapatnya, berkomunikasi dengan anak secara terbuka dan mau mendengarkan masalahnya. Kemudian dapat menghasilkan perilaku anak yang kooperatif, bersahabat, loyal, emosinya stabil, ceria dan bersikap optimis, mau menerima tanggung jawab, jujur, dapat dipercaya, memiliki perencanaan yang jelas untuk masa depan, dan bersikap realistik.

Senada dengan Schneiders dan Lore, Elizabeth (1990: 204) juga mengungkapkan bahwa penerimaan orang tua ditandai oleh perhatian besar dan kasih sayang pada anak. Orang tua yang menerima, memperhatikan perkembangan kemampuan anak dan memperhitungkan minat anak. Anak yang diterima umumnya bersosialisasi dengan baik, kooperatif, ramah, loyal, secara emosional stabil, dan gembira.

Berdasarkan pernyataan tersebut, dapat disimpulkan bahwa penerimaan orang tua terhadap anaknya dapat membawa dampak yang positif terhadap anak. Segala peran anak di akui oleh orang tua sehingga anak dapat memupuk rasa percaya diri yang tinggi dan mampu membangun dirinya dengan optimis. Dalam menciptakan prestasi belajar yang optimal, perhatian yang diberikan seharusnya diberikan secara maksimal pula. Di dalam proses pembelajaran yang dijalani oleh anak ada dua prinsip yang semestinya ditemukan orang tua di dalam diri anak.

Sementara menurut Linda dan Richard Eyre (1997: 49), potensi perlu ditemukan dalam diri anak sehingga bakat anak dan kemampuan anak dapat diketahui. Adanya potensi yang telah diketahui dapat membantu proses pembelajaran anak karena dapat memudahkan dalam membimbing anak. Potensi dalam hal ini adalah kemampuan 
atau bakat yang dimiliki anak untuk membangun dan mengembangkan dirinya. Sedangkan di sisi lain keandalan diri merupakan keandalan yang dimiliki anal dalam melakukan sesuatu. Dengan adanya keandalan diri ini anak akan dapat mengandalkan dirinya dalam berkarya dan melakukan sesuatu hal. Pemahaman dalam melakukan sesuatu juga turut dimiliki oleh anak. Anak akan mengerti mengenai sebab dan akibat dari perlakuan yang dilakukan dan selain itu anak akan cenderung menjadi seseorang yang bertanggung jawab atas kelakuan yang diperbuatnya. Karena pentingnya kedua prinsip ini maka perhatian dari orang tua sangat diperlukan.

Sebagaimana sudah diuraikan pada pembahasan sebelumnya, pola asuh orang tua merupakan pola sikap, metode dan cara bertindak, orang tua terhadap anakanaknya. Tujuan pola asuh orang tua adalah mendidik anak agar sesuai dengan potensi dan perkembangannya.

Mengulang pendapat McClelland, model pola asuh orang tua sangat berpengaruh terhadap motivasi berprestasi anak. Pada keluarga yang sehat dan bahagia, kata McClelland, pola asuh orang tua memotivasi anak untuk berprestasi. Orang tua model ini memberikan dorongan kepada anak untuk tidak menyerah, dan berusaha menyelesaikan tugas-tugasnya meski sulit sekalipun. Orang tua ini akan melarang anaknya mengeluh ketika menemui kesulitan atau kegagalan. Sebaliknya, orang tua model ini akan mendorong anak-anak mereka menemukan strategi dan cara terbaik menyelesaikan kesulitan atau menggapai kesuksesan. Ketika anak telah berhasil mengatasi kesulitan atau menggapai kesuksesan, orang tua tak akan segan memberikan apresiasi, pujian bahkan hadiah. Sementara menurut Dakir (1993: 114), pola asuh orang tua juga bisa dimaknai sebagai keaktifan perhatian orang tua yang dikerahkan untuk memberikan motivasi atau dorongan yang positif terhadap anaknya dalam usaha mencapai prestasi belajar yang seoptimal mungkin.

Berdasarkan pendapat-pendapat sebagaimana telah diuraikan, dapat diketahui bahwa pola asuh orang tua memiliki pengaruh yang signifikan terhadap motivasi berprestasi mahasiswa.

Penelitian yang dilakukan oleh Siska Eko Mawarsih (2013), dengan judul: Pengaruh Perhatian Orang Tua dan Motivasi Belajar terhadap Presatsi Belajar Siswa SMA Negeri Jumapolo, menemukan bahwa terdapat pengaruh yang signifikan motivasi belajar terhadap prestasi belajar siswa SMA Negeri Jumapolo. Untuk pengujian variabel perhatian orang tua dan motivasi belajar secara bersama-sama terhadap prestasi belajar siswa AMA 
Negeri Jumapolo diketahui terdapat pengaruh yang signifikan pula.

Penelitian yang dilakukan oleh Lydia Edmay Viveca David 2014, dengan judul: Pola Asuh Demokratis, Kemandirian Dan Motivasi Berprestasi Pada Mahasiswa, menemukan bahwa terdapat hubungan antara pola asuh demokratis dan kemandirian secara serentak dengan motivasi berprestasi. Selanjutnya Penelitian yang dilakukan oleh Lili Garliah 2005, dengan judul: Peran Pola Asuh Orang Dalam Motivasi Berprestasi, menemukan bahwa terdapat pengaruh yang signifikan pola asuh orang tua terhadap motivasi berprestasi mahasiswa. Lili Garliah dengan mengutip Eastwood, menegaskan bahwa pola asuh orang tua sangat mempengaruhi motivasi berprestasi anak. Selain pola asuh orang tua, rekan sejawat dan lingkungan sosial juga berpengaruh terhadap motivasi berprestasi mahasiswa.

Selanjutnya Lili Garliah dengan mengutip pendapat Ahmadi \& Sholeh, menyatakan bahwa pola asuh merupakan cara orang tua bertindak terhadap anakanaknya, di mana orang tua melakukan serangkaian tindakan usaha aktif. Pola asuh orang tua sangat berpengaruh terhadap motivasi berprestasi anak. Sebagai contoh pada umumnya anak selalu mengharap pujian dari orang tuanya.
Apabila pujian tersebut tidak diberikan, maka anak akan menjadi malas dan tidak mau belajar sehingga mereka akan mengalami kemunduran dalam motivasi berprestasi maupun prestasi belajar.

Penelitian yang dilakukan oleh Hastuti Naibaho 2010, dengan judul: Pengaruh Lingkungan Kampus Terhadap Motivasi Belajar Mahasiswa (Studi Kasus Universitas Pelita Harapan Surabaya), menemukan bahwa terdapat pengaruh yangsignifikan lingkungan kampus terhadap motivasi berprestasi mahasiswa. Lingkungan kampus yang kondusif dapat mempengaruhi prestasi belajar mahasiswa, sedangkan lingkungan kampus yang tidak sehat akan membuat mahasiswa merasa setres, menurunnya motivasi belajar mahasiswa yang pada akhirnya mempengaruhi prestasi belajarnya.

Hastuti Naibaho dengan mengutip Sihombing menyatakan bahwa lingkungan kampus adalah lingkungan di mana mahasiswa menjalani proses belajar dan melakukan aktivitas. Pengertian lingkungan kerja dapat memberikan kesamaan defenisi dari pengertian lingkugan kampus. Lingkungan kampus yang kondusif dapat meningkatkan motivasi belajar mahasiswa dalam rangka meningkatkan prestasi belajar mereka. Lingkungan kampus yang kondusif yang meliputi hubungan yang baik antara 
sesama mahasiswa serta hubungan antara mahasiswa dengan dosen, lingkungan fisik seperti ukuran kelas, suhu udara di dalam ruang kelas, pengendalian kebisingan, kebersihan kampus. Lingkungan kampus yang kondusif dapat mempengaruhi prestasi belajar mahasiswa. Lingkungan yang tidak sehat akan membuat mahasiswa merasa stres dan pada akhirnya menurunkan motivasi belajar mahasiswa yang pada akhirnya mempengaruhi motivasi berprestasinya.

Berdasarkan pertimbangan tersebut, perlu dilakukan penelitian yang bertujuan untuk mendapatkan data atau fakta yang tepat (sahih) dan dapat dipercaya tentang: (1) Hubungan antara lingkungan kampus dengan motivasi berprestasi mahasiswa FE-UNJ; (2) Hubungan antara perhatian orang tua denganmotivasi berprestasi mahasiswa FE-UNJ, dan (3) Hubungan antara lingkungan kampus dan pola asuh orang tua dengan motivasi berprestasi mahasiswa FE-UNJ.

\section{METODE PENELITIAN}

Penelitian ini menggunakan metode survei dengan pendekatan korelasi. Pendekatan korelasi digunakan untuk melihat pengaruh antara tiga variabel bebas yaitu lingkungan kampus dan pola asuh orang tua yang mempengaruhi dan diberi simbol $\mathrm{X}_{1}$ dan $\mathrm{X}_{2}$, dengan variabel terikat motivasi berprestasi sebagai yang dipengaruhi dan diberi simbol $\mathrm{Y}$. Pengumpulan data lingkungan kampus dan pola asuh pada mahasiswa digunakan kuesioner.

Teknik pengambilan sampel dalam penelitian ini menggunakan cluster rondom sampling. Menurut Sugiyono (2010: 121), teknik cluster rondom sampling ini bisa digunakan karena keterbatasan peneliti, sumber data sangat luas, serta tanpa memperhatikan strata yang ada dalam populasi tersebut. Berdasarkan pendapat Sugiyono sebagaimana telah diuraikan, diambil sampel mahasiswa dari beberapa prodi yang ada di Fakultas Ekonomi UNJ, dengan kriteria sudah ditentukan maka jumlah keseluruhan sampel adalah 150 orang mahasiswa.

Penelitian ini menggunakan teknik analisis deskriptif dan analisis inferensial. Analisis deskriptif digunakan untuk melihat gambaran data dari masing-masing variabel yang dinyatakan melalui mean, median, modus, distribusi frekuensi dan histogram. Selanjutnya dengan menganalisa data parameter model regresi yang akan digunakan. Pengolahan data dalam penelitian ini menggunakan program SPSS versi 22.0.

HASIL DAN PEMBAHASAN 
Berdasarkan penelitian ini ditemukan bahwa terdapat hubungan yang signifikan antara lingkungan kampus $\left(\mathrm{X}_{1}\right)$ dengan motivasi berprestasi (Y). signifikansi hubungan antara $\left(\mathrm{X}_{1}\right)$ dengan $(\mathrm{Y})$ dipertegas dengan hasil pengujian hipotesis yang diajukan dalam penelitian ini, yakni terdapat hubungan antara lingkungan kampus terhadap motivasi berprestasi. Dengan demikian, peningkatan atau perbaikan kualitas lingkungan kampus akan berdampak pada peningkatan motivasi berprestasi mahasiswa FE-UNJ. Hasil penelitian menunjukkan bahwa ada korelasi signifikan antara lingkungan kampus dengan motivasi berprestasi mahasiswa Pendidikan Akuntansi FE-UNJ, di mana koefisien korelasi ganda $\left(\mathrm{R}_{\mathrm{y} .12}\right)=$ 0,196 dan $\mathrm{F}$ hitung $(\mathrm{F}$ Change $)=11,144$, serta $\mathrm{p}$-value $=0,040<0,05$. Sedangkan koefisien determinasinya $\mathrm{R}$ square $=0,038$, yang mengandung makna bahwa 3,8\% variasi nilai pada variabel motivasi berprestasi (Y) dapat dijelaskan oleh lingkungan kampus $\left(\mathrm{X}_{1}\right)$. Dengan demikian, hipotesis terdapat hubungan antara lingkungan kampus terhadap motivasi berprestasi mahasiswa FE-UNJ diterima.

Hasil penelitian ini logis, karena lingkungan kampus merupakan aspek penting bagi kegiatan perkuliahan. Jika lingkungan kampus tidak nyaman dan tidak kondusif, bukan saja mengurangi motivasi berprestasi mahasiswa tetapi juga bisa jadi membuat mereka stres dan tidak mampu mencapai target prestasi yang sudah ditentukan. Lingkungan sosial kampus juga memengaruhi prestasi belajar mahasiswa. Sebagai contoh kerja sama antar mahasiswa yang baik, memicu mahasiswa untuk mengarahkan diri dengan upaya maksimal dalam menentukan tujuan jangka panjang. Kerja sama yang baik antar mahasiswa juga membuat lingkungan kampus menjadi kondusif, dan mendukung suasana akademik. Lebih dari itu, adanya sikap saling menghargai antar mahasiswa, menjadikan mereka dapat memilih untuk dapat memahami secara jelas tugas yang diberikan, siap menerima kesalahan dan kegagalan mereka, serta tidak mencela nasib buruk atas kegagalan yang mereka alami.

Sebagaimana sikap saling menghargai, suri teladan di lingkungan kampus juga memengaruhi mahasiswa dalam melakukan usahanya untuk berprestasi yang lebih baik, mereka tidak menyukai peluang yang belebihan terhadap keberhasilan mereka, serta tidak menyukai tugas/pekerjaan yang terlalu mudah bagi mereka. Dengan kata lain, suri tauladan menjadikan semacam role model yang bisa diikuti dan menuntun mahasiswa pada 
keberhasilan di samping meningkatkan motivasi berprestasi.

Selain itu, kepuasan siswa terhadap lingkungan kampusnya menjadikan mereka lebih bergairah dalam meningkatkan usahanya untuk mengejar prestasi. Sarana dan prasarana yang baik juga menjadikan mereka ingin melakukan upaya ekstra mereka untuk meraih tujuan. Oleh karena itu, agar motivasi berprestasi mahasiswa tinggi, maka sebaiknya lingkungan kampus ditata dan diatur sedemikian rupa.

Hasil penelitian ini juga mendukung penelitian sebelumnya yang sudah dilakukan oleh Hastuti Naibaho (2010). Berdasarkan penelitian Hastuti Nasution diketahui bahwa lingkungan kampus yang kondusif dapat mempengaruhi prestasi belajar mahasiswa. Sebaliknya lingkungan kampus yang tidak kondusif dan tidak sehat akan membuat mahasiswa kurang nyaman dalam belajar bahkan tidak menutup kemungkinan mereka aka stres. Jika mahasiswa sudah merasa tidak nyaman di lingkungan kampus demikian, maka alih-alih motivasi berprestasi mereka tinggi, yang ada justru motivasi belajar akan rendah.

Selanjutnya, pendapat dari Nana Syaodih Sukmadinata (2005), Dimyati dan Mudjiono (2013) juga semakin mempertegas bahwa semakin baik lingkungan kampus, semakin baik pula motivasi berprestasi mahasiswa. Demikian pula sebaliknya, semakin buruk lingkungan kampus maka akan semakin buruk pula motivasi berprestasi mahasiswa. Dengan demikian, peningkatan kualitas lingkungan kampus akan berbanding lurus dengan motivasi berprestasi mahasiswa.

Berdasarkan penelitian juga ditemukan bahwa terdapat hubungan yang signifikan antara pola asuh orang tua $\left(\mathrm{X}_{2}\right)$ dengan motivasi berprestasi (Y). signifikansi hubungan antara $\left(\mathrm{X}_{2}\right)$ dengan (Y) dipertegas dengan hasil pengujian hipotesis yang diajukan dalam penelitian ini yakni terdapat hubungan antara pola asuh orang tua terhadap motivasi berprestasi. Dengan demikian, pola asuh orang tua yang baik di lingkungan keluarga akan berdampak pada peningkatan motivasi berprestasi mahasiswa FE-UNJ.

Hasil penelitian menunjukkan bahwa ada hubungan yang signifikan antara pola asuh orang tua terhadap motivasi berprestasi mahasiswa FE-UNJ, di mana koefisien korelasi $\mathrm{X}_{2}$ ke $\mathrm{Y}$ sebesar 0,102 dengan nilai signifikansi $0,000 \leq$ 0,050. Hasil hitung koefisien korelasi ganda $\left(\mathrm{R}_{\mathrm{y} .12}\right)=0,410$ dan $\mathrm{F}$ hitung $(\mathrm{F}$ Change) $=21,817$, serta $p$-value $=0,000<$ 0,05 . Sedangkan koefisien determinasinya, yaitu $\mathrm{R}$ square $=0,168$, mengandung makna bahwa 16,8 \% variasi nilai pada 
variabel motivasi berprestasi (Y) dapat dijelaskan oleh pola asuh $\left(\mathrm{X}_{2}\right)$.

Hasil penelitian ini logis, karena pola asuh orang tua berpengaruh terhadap motivasi berprestasi anak. Orang tua yang mempunyai kontrol positif yang tinggi terhadap anak, menjadikan anak-anak merasa disayangi oleh kedua orang tuanya. Hal ini menjadikan mereka dapat mengarahkan diri dengan maksimal untuk menentukan tujuan jangka panjangnya. Orang tua yang responsif terhadap kebutuhan anak, memengaruhi anak dalam bersikap, sehingga anak melakukan upaya ekstra demi mencapai tujuannya Selain itu, orang tua yang mengajarkan tanggung jawab, menjadikan anak siap menerima kesalahan-kesalahan yang telah mereka lakukan penyebab kegagalan mereka.

Anak-anak yang tumbuh dalam rumah yang penuh rasa cinta, menjadikan mereka lebih responsif dalam melaksanakan tugas-tugas dengan baik dengan rasa cinta pula. Ada aturan, disiplin, dan hukuan positif dari orang tua juga menjadikan anak menjadi lebih bertanggung jawab dan siap menerima konsekuensi atas kesalahannya. Hal ini berimbas pada motivasi mereka untuk mewujudkan cita-citanya.

Mengulang pendapat McClelland, pada keluarga yang sehat dan bahagia, pola asuh orang tua memotivasi anak untuk berprestasi. Orang tua model ini memberikan dorongan kepada anak untuk tidak menyerah, dan berusaha menyelesaikan tugas-tugasnya meski sulit sekalipun. Orang tua ini akan melarang anaknya mengeluh ketika menemui kesulitan atau kegagalan. Sebaliknya, orang tua model ini akan mendorong anakanak mereka menemukan strategi dan cara terbaik menyelesaikan kesulitan atau menggapai kesuksesan. Ketika anak telah berhasil mengatasi kesulitan atau menggapai kesuksesan, orang tua tak akan segan memberikan apresiasi, pujian bahkan hadiah

Senada dengan McClelland, Rohner sampai pada kesimpulan bahwa pola asuh berpengaruh pada belajar dan prestasi belajar anak. Pola asuh juga menjadi prediktor yang memengaruhi perkembangan dalam kemampuan sosial, akademik, perkembangan psikososial, bahkan pembentukan prilaku yang bermasalah. Begitu penting dan berartinya pola asuh orang tua terhadap anak, sampaisampai Rohner menyimpulkan bahwa pengalaman masa kecil seseorang sangat mempengaruhi perkembangan kepribadian- nya kelak - termasuk karakter atau kecerdasan emosinya. Penelitian Rohner yang menggunakan teori PAR (Parental Acceptance-Rejection Theory) ini juga menyimpulkan bahwa pola asuh 
orang tua, baik yang menerima (acceptance) atau yang menolak (rejection) anaknya, akan mempengaruhi perkembangan emosi, perilaku, sosialkognitif, dan kesehatan fungsi psikologisnya ketika dewasa kelak.

Senada dengan McClelland dan Rohner, Haditono (Mönks \& Knoers, 1999) menegaskan bahwa pola asuh orang tua dapat mempengaruhi pembentukan motivasi berprestasi pada anak, serta mendorongnya melebihi standar keunggulan. Apalagi pada umumnya, anak mengharapkan pujian dari orang tua. Apabila orang tua tidak memberikan pujian kepada anak, maka ia akan menjadi pemalas dan tidak mau belajar. Dengan demikian, jangankan prestasi belajarnya tinggi, bisa jadi anak akan mengalami kemunduruan dalam hal prestasi belajarnya.

Hasil penelitian ini juga mendukung penelitian sebelumnya yang dilakukan oleh Lili Garliah (2005). Berdasarkan penelitian Lili Garliah diketahui bahwa pola asuh orang tua memiliki hubungan dan pengaruh yang signifikan terhadap motivasi berprestasi mahasiswa. Penelitian yang dilakukan oleh Dwinta Astri Meirizki (2010), juga mengungkap hal sama bahwa ada hubungan yang signifikan antara pola asuh orang tua dengan motivasi berprestasi mahasiswa. Demikian pula hasil penelitian yang dilakukan oleh Lydia Edmay Viveca David (2014), mempertegas bahwa ada hubungan yang signifikan antara pola asuh dengan motivasi berprestasi mahasiswa. Berdasarkan pembahasan hasil pengujian data dan kajian literatur di atas maka dapa disimpulkan bahwa hipotesis kedua yaitu terdapat hubungan antara pola asuh orang tua terhadap motivasi berprestasi mahasiswa FE-UNJ diterima.

Selain dua temuan sebagaimana telah diuraikan, berdasarkan penelitian ini juga ditemukan bahwa terdapat hubungan yang signifikan antara lingkungan kampus $\left(\mathrm{X}_{1}\right)$ dan pola asuh orang tua $\left(\mathrm{X}_{2}\right)$ secara bersama-sama terhadap motivasi berprestasi (Y). Signifikansi hubungan antara $\left(\mathrm{X}_{1}\right)$ dan $\left(\mathrm{X}_{2}\right)$ terhadap $(\mathrm{Y})$ dipertegas dengan hasil pengujian hipotesis yang diajukan dalam penelitian ini, yakni terdapat hubungan antara lingkungan kampus dan pola asuh orang tua terhadap motivasi berprestasi. Dengan demikian, lingkungan kampus yang kondusif dan pola asuh orang tua yang baik di lingkungan keluarga akan berdampak pada peningkatan motivasi berprestasi mahasiswa FE-UNJ.

Hasil penelitian menunjukkan bahwa ada hubungan yang signifikan antara lingkungan kampus dan pola asuh orang tua terhadap motivasi berprestasi 
mahasiswa Pendidikan Akuntansi FE-UNJ di mana hasil perhitungan uji koefisien korelasi ganda $\left(\mathrm{R}_{\mathrm{y} .12}\right)=0,415$ dan $\mathrm{F}$ hitung $($ F Change $)=11,144$, serta $p$-value $=0,000$ $<\quad 0,05$. Sedangkan koefisien determinasinya, yaitu $\mathrm{R}$ square $=0,172$, yang mengandung makna bahwa 17,2 \% variasi nilai pada variabel motivasi berprestasi (Y) dapat dijelaskan oleh lingkungan kampus $\left(\mathrm{X}_{1}\right)$ dan pola asuh $\left(\mathrm{X}_{2}\right)$ secara bersama-sama.

Lingkungan kampus dan pola asuh yang baik memengaruhi anak dalam motivasi berprestasinya. Sebagai contoh ketika lingkungan sosial kampus yang terdapat budaya yang saling menghargai serta adanya orang tua yang responsif terhadap kebutuhan anak, menjadikan anak dapat mengarahkan dirinya untuk dapat berupaya dengan maksimal dalam mencapai prestasinya.

Contoh lain misalnya, ketika saran dan prasarana kampus berkolaborasi dengan kontrol positif yang baik, serta diberikannya tanggung jawab anak dari orang tua, menjadikan anak dapat mengarahkan dirinya untuk dapat berprestasi serta berani mengambil sebuah resiko, serta siap menerima kesalahankesalahan yang telah dibuatnya untuk mencapai prestasi yang lebih baik. Penelitian ini juga dapat dimaknai bahwa peningkatan kualitas lingkungan kampus dan pola asuh orang tua yang baik akan berdampak signifikan terhadap kenaikan motivasi berprestasi mahasiswa. Dengan demikian, hipotesis terdapat hubungan antara lingkungan kampus dan pola asuh orang tua terhadap motivasi berprestasi dapat diterima.

Berdasarkan pembahasan dan analisis data, maka dapat diketahui bahwa penelitian ini memiliki keterbatasan karena hanya menguji dua variabel $\left(\mathrm{X}_{1}\right.$ dan $\left.\mathrm{X}_{2}\right)$, sehingga tidak melihat pengaruh variabel yang lain $\left(\mathrm{X}_{3}, \mathrm{X}_{4}\right.$ dan seterusnya) terhadap Y. Oleh karena itu, bisa saja peningkatan Y juga dipicu oleh variabel-variabel lain seperti $\mathrm{X}_{2}, \mathrm{X}_{3}$ dan sebagainya. Peneliti hanya menyebar kuesioner saja, sehingga tidak melihat proses bagaimana responden mengisinya. Dalam hal ini, bisa saja terjadi faktor psikologis responden pada saat itu ada yang kurang baik, sehingga dapat mempengaruhi responden dalam mengisi kuesioner.

\section{SIMPULAN DAN SARAN}

Berdasarkan hasil analisa data dan pembahasan dapat ditarik kesimpulan bahwa: (1) Terdapat hubungan yang signifikan antara lingkungan kampus dengan motivasi berprestasi mahasiswa FE-UNJ; (2) Terdapat hubungan yang signifikan antara pola asuh orang tua dengan motivasi berprestasi mahasiswa 
FE-UNJ, dan (3) Terdapat hubungan yang signifikan antara lingkungan kampus dan pola asuh orang tua terhadap motivasi berprestasi mahasiswa FE-UNJ.

Berdasarkan hasil analisa data, pembahasan dan temuan empirik penelitian ini, menunjukkan bahwa kedua variabel yakni lingkungan kampus dan pola asuh orang tua berpengaruh langsung positif terhadap motivasi berprestasi mahasiswa FE-UNJ. Hal ini menandakan jika akan meningkatkan motivasi berprestasi, maka kedua variabel yakni lingkungan kampus dan pola asuh orang tua harus dipertimbangkan, mengingat peningkatan kedua variabel tersebut akan meningkatkan motivasi berprestasi mahasiswa Pendidikan Akuntansi FE-UNJ. Kendati demikian, dari setiap variabel terdapat indikator-indikator yang memperoleh skor terendah. Hal ini menandakan bahwa indikator yang memperoleh skor terendah memerlukan strategi atau perlakuan khusus sehingga ke depan skornya bisa ditingkatkan.

Pada variabel lingkungan kampus $\left(\mathrm{X}_{1}\right)$, skor terendah diperoleh indikator nomor 11 yaitu, "akses internet cepat dan dapat diandalkan." Adapun skor tertinggi diperoleh indikator nomor 9 yaitu, "layar proyektor tersedia di setiap kelas." Pada variabel pola asuh orang tua $\left(\mathrm{X}_{2}\right)$, skor terendah diperoleh indikator nomor 14, yaitu: "orang tua tidak membatasi jam bermain anak." Adapun skor tertinggi diperoleh indikator nomor 7, yaitu: "orang tua selalu memberikan kepercayaan kepada anak dalam belajar." Selanjutnya pada variabel motivasi berprestasi (Y), skor terendah diperoleh indikator nomor 16, yaitu: "saya selalu mempercayakan tugas kepada orang lain berdasarkan kompetensinya." Adapun skor tertinggi diperoleh indikator nomor 1, yaitu: "saya selalu menginginkan penjelasan tentang tugas yang diberikan kepada saya."

Berdasarkan hasil penelitian, pembahasan, simpulan dan implikasi yang telah diuraikan di atas, maka dalam upaya lebih meningkatkan motivasi berprestasi mahasiswa FE-UNJ, peneliti memberikan saran-saran sebagai berikut: Pertama, Fakultas Ekonomi UNJ, perlu lebih meningkatkan lagi penyediaan lingkungan kampus yang kondusif. Berdasarkan perolehan skor terendah pada variabel lingkungan kampus $\left(\mathrm{X}_{1}\right)$, yaitu "akses internet cepat dan dapat diandalkan," maka perlu dilakukan pembenahan jaringan internet sehingga mahasiswa bisa mudah mengaksesnya. Dengan kata lain, penyediaan akses internet yang cepat dan dapat diandalkan, dapat meningkatkan motivasi berprestasi mahasiswa FE-UNJ.

Kedua, bagi orang tua, berdasarkan perolehan skor terendah pada variabel pola 
asuh orang tua $\left(\mathrm{X}_{2}\right)$ yaitu pada indikator "orang tua tidak membatasi jam bermain anak, " maka sebaiknya perlu dirubah. Dengan kata lain, orang tua harus membatasi jam bermain anak. Hal ini logis, sebab jika dihabiskan untuk bermain maka waktu anak untuk belajar menjadi kurang. Lebih dari itu, orang tua hendaknya menerapkan pola asuh yang baik sehingga anak mereka memiliki motivasi berprestasi yang tinggi.

Ketiga, bagi dosen, kemampuan memotivasi mahasiswa harus lebih ditingkatkan lagi. Bedasarkan perolehan skor terendah pada variabel motivasi berprestasi $(\mathrm{Y})$ yaitu pada indikator nomor 16, maka para dosen harus mampu meyakinkan mahasiswa bahwa menyerahkan tugas pada seseorang berdasarkan kompetensi itu tindakan yang tepat. Rendahnya skor bisa jadi karena para mahasiswa masih ragu bahkan kurang percaya bahwa menyerahkan tugas pada seseorang sesuai kompetensi itu sebagai tindakan yang tepat. Dan keempat, bagi para peneliti disarankan untuk melakukan penelitian lanjutan dalam populasi dan sampel yang lebih luas dalam kaitannya dengan lingkungan kampus, pola asuh orang tua, dan motivasi berprestasi. Di samping itu perlu dilakukan penelitian lanjutan tentang pengembangan model lingkungan kampus dan pola asuh orang tua yang bisa lebih meningkatkan motivasi berprestasi mahasiswa FE-UNJ. Mengingat pentingnya motivasi berprestasi bagi kesuksesan studi/akademik maupun pengembangan diri mahasiswa di masa mendatang.

\section{DAFTAR PUSTAKA}

Anis Diah Ayu Masita Mencetak Generasi Masa Depan, 2014. Error! Hyperlink reference not valid.. (Diakses pada tanggal 16 Februari 2015.

Chasiyah, Chadidjah, \& Legowo, Edy. 2009. Perkembangan Peserta Didik. Surakarta: UNS Press.

Dakir. 1993. Dasar-dasar Psikologi. Yogyakarta : Pustaka Pelajar.

Dale H. Schunk. 2004. Encyclopedia of Applied Psychology, Edited by Charles D. Spielberger, Florida: Elsevier.

Depdiknas. 2003. Undang-undang (UU) Republik Indonesia No. 20 Tahun 2003 Tentang Sistem Pendidikan Nasional,Jakarta: Departemen Dalam Negeri.

Dimyati dan Mudjiono. 2013. Belajar dan

Pembelajaran. Jakarta : Rineka Cipta.

Djaali. 2009. Psikologi Pendidikan. Jakarta: Bumi Aksara.

Duwi Priyatno. 2010. Paham Analisa

Statistik Data dengan SPSS. Yogyakarta : Mediakom.

Dyah Retno Palupi, "Hubungan Antara Motivasi Berprestasi Dan Persepsi Terhadap Pola Asuh Orang Tua Dengan Prestasi Belajar Mahasiswa Psikologi Angkatan 2010 Universitas 
Airlangga Surabaya", Jurnal Psikologi Pendidikan dan Perkembangan, Vol. 2, No. 01, Februari 2013.

Eddy Soeryanto Soegoto. 2010. Entrepreneurship: Menjadi Pebisnis Ulung, Jakarta: Elex Media Komputindo.

Elizabeth B. Hurlock. 1990. Perkembangan Anak Terj. Meitasari Tjandrasa. Jakarta: Erlangga.

Falko Rheinberg, Regina Vollmeyer, and Bruce D. Burns. 2000. Motivational Psychology of Human Development: Developing Motivation and Motivating Development, Edited by J. Heckhausen, Amsterdam: Elsevier Science B.V.

Hall, C. \& Lindsey, G. 1995. Introduction to theories of Personality, New York: Jhon Wiley and Sons.

Hastuti Naibaho, "Pengaruh Lingkungan Kampus Terhadap Motivasi Belajar Mahasiswa (Studi Kasus Universitas Pelita Harapan Surabaya)", Jurnal Manajemen Pemasaran, Vol. 5, No 1, April 2010.

Kenneth T. Henson \& ben F. Elle. 1997.

Education Psychology For Effective Teaching, Boston:Wadsworth.

Lili Garliah, "Peran Pola Asuh Orang Tua Dalam Motivasi Berprestasi," Jurnal Psikologia, Volume I, No 1, h. 1-47, Juni 2005.

Linda dan Richard Eyre. 1997. Mengajakrkan Nilai-Nilai Kepada Anak, Penerjemah Ales Tri Kartjono, Jakarta : Gramedia Pustaka Umum. Logan Wright. 1987. Dua Puluh Prinsip Mengasuh Anak Modern, Penerjemah : Rafael H, Jakarta : Mega Media Anak.
Lydia Edmay Viveca David,"Pola Asuh Demokratis, Kemandirian Dan Motivasi Berprestasi Pada Mahasiswa,"Jurnal Psikologi Indonesia, Vol. 3, No. 01, hal 65 70, Januari 2014.

Roberta M. Berns. 2010. Child, Family, School, Community: Socialization and Support, Eighth Edition, USA: Wadsworth, Cengage Learning.

Saifuddin Azwar. 1996. Tes Prestasi: Fungsi dan Pengembangan Pengukuran Prestasi Belajar (Edisi II). Yogyakarta: Pustaka Pelajar.

Siska Eko Mawarsih. 2013. "Pengaruh Perhatian Orang Tua dan Motivasi Belajar terhadap Presatsi Belajar Siswa SMA Negeri Jumapolo," Jurnal Pendidikan Universitas Negeri Solo, Vol 1, h. 1-13.

Slameto. 2010. Belajar dan faktor-faktor yang mempengaruhinya, Jakarta: Rineka Cipta.

Toto Tasmara. 2006. Spiritual Centered Leadership; KepemimpinanBerbasis Spiritual, Jakarta: Gema Insani.

Winkel. 1999. Psikologi Pengajaran. Yogyakarta: Media abadi. 
Makmun Khairani. 2014. Psikologi Belajar. Yogyakarta: Aswaja.

Muhibbin Syah. 2008. Psikologi Belajar. Bandung: PT Remaja Rosdakarya.

Nana Syaodih Sukmadinata. 2005. Landasan Psikologi Proses Pendidikan. Bandung: PT Rosdakarya. Muhammad Karebet Widjajakusuma 2008. Be The Best: Not "Be Asa", Jakarta: Prestasi.

Mirza S. Saiyadain. 2006. Organisational Behaviour, New Delhi: Tata McGrawHill.

Robert E.Salvin. 1991. Educational Psychology; Theory Into Practice, United States Of America : PrenticeHall International, Inc. 